
ISSN : 2615-1995, E-ISSN : 2615-0654

J. Madani., Vol. 2, No. 2, September 2019 (289 - 303)

(C)2018 Lembaga Kajian Demokrasi

MADANI

dan Pemberdayaan Masyarakat (LKD-PM)

\title{
Persepsi Guru Tentang Kompetensi Supervisi Kepala Sekolah dan Profesional Guru Dengan Kinerja Guru di SMA 1926 Pamulang
}

\author{
Endang Susilo Wardani \\ Fakultas Ekonomi, Universitas Pamulang \\ dosen01645@unpam.ac.id
}

\begin{abstract}
Abstrak
Dapat diketahui bahwa kepemimpinan adalah bagaimana cara seorang pemimpin. Dengan Persepsi adalah proses seseorang mengetahui beberapa hal melalui pancaindranya. Dalam hal kemampuan memahami hal tanpa mempelajari, mengarahkan, memotivasi, dan mengatur semua elemen yangada di dalam suatu organisasi untuk direalisasikan pada tujuan yang akan dicapai, sehingga akan membawa kinerja guru yang maksimal, untuk mencapai tujuan itu harus diatur bahwa seorang pemimpin harus memiliki sifat kepemimpinan yang dapat membawa motivasi pada jalur yang tepat untuk guru, sehingga target atau tujuan yang direncanakan akan tercapai. Kompetensi adalah kewenangan kekuasaan untuk menentukan memutuskan sesuai, Selain itu, pemimpin akan memberikan promosi kepada guru yang berhasil dalam mencapai target dan akan membawa kepuasan kerja sebagai tujuan akhir. Dengan memberikan kompensasi, guru akan memiliki rasa kepuasan kerja bersamaan dengan semangat kerja yang bernilai tinggi, untuk mencapai target. Profesional memerlukan kepandaian khusus untuk menjalankannya, Kepuasan Kerja adalah salah satu keinginan secara emosional guru yang akan terjadi atau tidak, antara nilai remunerasi dari organisasi dengan remunerasi oleh guru di luar harapan. kinerja prestasi yang diperlihatkan. Kepemimpinan dapat disebut sebagai salah satu usaha seorang pemimpin, dalam mengarahkan, mengatur dan memberikan dorongan semua unsur unsur dalam sebuah organisasi, untuk mewujudkan suatu tujuan yang akan dicapai, sehingga akan memerikan hasil kinerja guru yang maksimal. Penelitian ini bertujuan untuk mengetahui persepsi guru tentang kompetensi supervisi kepala sekolah. Ini adalah penelitian deskriptif. Populasi adalah 24 guru dan sampel adalah 24 orang yang diambil dengan menyebarkan bentuk kuisioner. Data dikumpulkan dengan kuesioner yang dibagikan kepada 24 responden SMA 1926 Pamulang. Dari 3 variabel bebas ini yang akan diuji secara individual, tipe kepemimpinan yang dominan yang mempengaruhi kepuasan kerja adalah tipe otoriter $\left(X_{2}\right)$. Secara umum, persepsi guru tentang kompetensi supervisi kepala sekolah SMA (SMA Negeri 1926 Pamulang). Dari penelitian dapat dikatakan bahwa Kompetensi Supervisi kepala sekolah memuaskan.
\end{abstract}

Kata Kunci : Kompetensi, Supervisi, Profesional

\section{Abstract}

Leadership we can say, the way of a leader. In intuition directing, motivating, and arrangement all element that inside of an organization to realize on a purpose that will to acomplish, so that will bring maximal teacher's performance, to achieve that goal should be arrange that a leader must have the leadership can bring the motivation on the right track to the teacher, that so the target or goal that planned will be accomplish altogether. Beside that leader will promote to the teacher that succeed the achievement and will bring work satisfaction a long the aim of the goal. By giving the compensation, teacher wil have work satisfaction along with high value working spirit, to achieve the target. Work Satisfaction is one of circumstance of teacher emotional that will happen or not, between value of remuneration from organization with the remneration by the teacher beyond 
expectation. This study aims to determine teachers' perceptions of supervision competency the headmaster. This is a descriptive study. The population is 24 teachers and the sample is 24 people that taken byfield collection and questioner that have been spread. And data collected by questionaire that shared to 24 respondent SMA 1926 Pamulang. From this independent 3 variable that will be tested by individualy, the dominancy leadershipp type that affecting work satsfaction is authoritarian type $\left(X_{2}\right)$. In general, teachers' perceptions of the supervision competency of headmaster SMA (senior High School 1926 Pamulang. From the research it can be said that Supervision Competency of headmaster is satisfy

Keywords : Perception, Competencies, Supervision.

\section{PENDAHULUAN}

\section{Latar Belakang}

Pendidikan mempunyai peranan penting dalam upaya meningkatkan kualitas sumber daya manusia. Usaha untuk dapat meningkatkan kualitas sumber daya manusia tersebut adalah melalui proses pembelajaran. Untuk itu sekolah memegang peranan penting dalam mempersiapkan mereka. Karena sekolahlah yang merupakan lembaga formal yang diserahi tanggung jawab oleh pemerintah untuk memebentuk manusia seutuhnya. Maka dari itu sekolah harus bisa menjalankan pendidikan dengan baik dan didukung oleh kompetensi kepala sekolah.

Menurut Mulyasa Kepala sekolah merupakan salah satu komponen pendidikan yang paling berperan dalam meningkatkan kualitas pendidikan, karena kepala sekolah adalah pengelola pendidikan pada satuan pendidikan atau pada tingkat sekolah. Maka dari itu, kepala sekolah bertanggung jawab terhadap maju mundurnya sekolah. Sebagaimana yang dicantumkan dalam Peraturan Pemerintah Republik Indonesia No. 28 tahun 1990 tentang pendidikan dasar pasal 12 ayat 1 yang berbunyi: "Kepala sekolah bertanggung jawab atas penyelenggaraan kegiatan pendidikan, administrasi sekolah, pembinaan tenaga pendidikan lainnya dan pendayagunaan serta pemelihara sarana dan prasarana".

Sehubungan dengan hal tersebut, dapat dilihat sukses tidaknya pendidikan dan pembelajaran di sekolah sangat dipengaruhi oleh kemampuan kepala sekolah dalam setiap komponen sekolah (who is behind the school). Kemampuan tersebut menyangkut pengetahuan dan pemahaman mereka terhadap manajemen dan kepemimpinan, serta tugas yang dibebankan kepadanya, kare- na tidak jarang kegagalan pendidikan dan pembelajaran di sekolah disebabkan oleh kepala sekolah kurang paham terhadap tugas-tugas yang harus dilaksanakannya.

Pemimpin oleh Winardi (2004:304) didefinisikan sebagai berikut :"Pemimpin adalah seorang yang karena kecakapan-kecakapan pribadinya dengan atau tanpa pengangkatan resmi dapat mempengaruhi kelompok yang dipimpinnya untuk mengerahkan usaha bersama ke arah pencapaian sasaran-sasaran tertentu“. Oleh karena itu, kepala sekolah dituntut menguasai kompetensi yang harus dikuasainya. Peraturan Menteri Pendidikan Nasional Republik Indonesia Nomor 13 Tahun 2007 menjelaskan tentang standar kepala sekolah.

Salah satu kompetensi yang harus dikuasai oleh kepala sekolah adalah kompetensi supervisi. Kompetensi supervisi ini merupakan kompetensi penting dikuasai oleh kepala sekolah, disamping kompetensi lain. Kompetensi supervisi kepala sekolah dapat didefenisikan sebagai kemampuan kepala sekolah dalam memberikan pembinaan kepada guru untuk memperbaiki kualitas pembelajaran. Wahyudi (2009:28) mengartikan kompetensi sebagai kemampuan melaksanakan sesuatu yang diperoleh melalui pendidikan dan latihan dengan standar dan kualitas tertentu sesuai tugas yang akan dilaksanakan.

Gordon dalam Makawimbang, H. Jerry (2012:63) menjelaskan beberapa aspek atau ranah yang terkandung dalam konsep kompetensi sebagai berikut:

- Pengetahuan (knowledge) yaitu kesadaran dalm bidang kognitif;

- Pemahaman (understanding), yaitu kedalaman kognitif; 
- Kemampuan (skill), yaitu sesuatu yang dimiliki oleh individu untuk melakukan tugas atau pekerjaan yang dibebankan kepadanya;

- Nilai (values), yaitu suatu standar perilaku yang diyakini dan secara psikologis telah menyatu dalam diri seseorang;

- Sikap (attitude), yaitu perasaan (senangtidak senang, suka-tidak suka) atau reaksi terhadap suatu rangsangan yang datang dari luar;

- Minat (interest), yaitu kecenderungan seseorang untuk melakukan sesuatu perbuatan. Supervisi merupakan aktivitas menentukan kondisi/syarat yang esensial, yang akan menjamin tercapainya tujuan-tujuan pendidikan. Orientasi supervisi dapat dikatakan sebagai proses pembantuan. Dengan kata lain, pembatuan dalam pengembangan situasi belajar mengajar agar memperoleh kondisi yang lebih baik. Supervisi tertuju pada perkembangan guru-guru dan personel sekolah lainnya dalam usaha mencapai tujuan pendidikan. Dalam hal ini supervisi dapat dilakukan melalui dorongan, bimbingan dan pemberian kesempatan.

Piet A. Sahertian (2008:19): menjelaskan supervisi adalah usaha member layanan kepada guru-guru baik secara individual maupun secara kelompok dalam usaha memperbaiki pengajaran Menurut Wakawimbang kompetensi supervisi adalah kemampuan, keterampilan dan kecakapan yang dimliki kepala sekolah dalam memberikan pembinaan kepada guru untuk meningkatkan profesionalisme guru. Namun, dari hasil observasi dan wawancara dengan 30 orang guru di SMA 1926 Pamulang pada tanggal 30 Oktober- 2 November 2012 terlihat masih ada beberapa orang kepala sekolah belum sepenuhnya menguasai kompetensi supervisi kepala sekolah. Hal ini terlihat dari beberapa fenomena yang terjadi, yaitu:

- Supervisi yang dilakukan kepala sekolah belum direncanakan dengan baik, karena supervisi dilaksanakan atas dasar keinginan dari kepala sekolah sendiri tanpa melibatkan guru, sehingga tidak jelas jadwal kegiatan supervisi;

- Pelaksanaan supervisi yang dilakukan kepala sekolah belum berpedoman kepada proses atau langkah-langkah yang benar, sehingga pelaksanaan supervisi cenderung mencari kesalahan guru;

- Tindak lanjut terhadap pelaksanaan supervisi jarang dilakukan, akibatnya sulit memberikan umpan balik untuk memperbaiki pelaksanaan supervisi yang akan datang, karena kurangnya informasi tentang hasil yang telah dicapai.

Masalah diatas timbul karena kepala sekolah kurang memahami bagaimana kompetensi supervisi kepala sekolah. Berdasarkan Permendiknas No. 13 Tahun 2007, bahwa kompetensi supervisi meliputi:

1. Merencanakan program supervisi akademik dalam rangka peningkatan profesionalisme guru.

2. Melaksanakan supervisi akademik dengan menggunakan pendekatan dan teknik supervisi yang tepat. Menindaklanjut hasil supervisi akademik dalam rangka peningkatan profesionalisme guru.

Adapun yang menjadi tujuan penelitian ini adalah untuk mendapatkan informasi tentang persepsi guru terhadap kompetnsi supervisi kepala sekolah dalam merencanakan program supervisi akademik, melaksanakan supervisi akademik dengan menggunakan pendekatan dan teknik yang tepat, dan menindaklanjut hasil supervisi akademik dalam rangka penngkatan profesionalisme guru. Hasil penelitian ini diharapkan berguna bagi semua pihak yang terkait dalam suatu organisasi, (1) Masukan bagi Kepala SMA 1926 dalam memberkan pembinaan kepada guru dalam melaksanakan proses belajar mengajar. (2) Masukan bagi pengawas dalam memberikan pembinaan terhadap kepala SMA 1926 yang ada di Pamulang. Pengertian persepsi menurut Rivai, Veithzal mengatakan (2011:326), "persepsi merupakan suatu proses dimana individu-individu mengorganisasikan dan menafsirkan kesan indera mereka agar member makna kepada lingkungan mereka. Disamping itu, persepsi dapat pula dilihat dari proses kognitif yang dialami oleh setiap orang dalam memahami informasi tentang lingkungannya, baik lewat 
penglihatan, pendengaran, penghayatan dan penciuman.

Sahertian dalam Wahyudi (2009:28) mengartikan kompetensi sebagai kemampuan melaksanakan sesuatu yang diperoleh melalui pendidikan dan latihan dengan standar dan kualitas tertentu sesuai tugas yang akan dilaksanakan. Sedangkan Supandi dalam Wahyudi (2009:28) bahwa kompetensi adalah seperangkat kemampuan untuk melakukan sesuatu jabatan, dan bukan semata-mata pengetahuan saja. Kepala sekolah merupakan pemimpin pendidikan tingkat satuan pendidikan yang harus memiliki dasar kepemimpinan yang kuat. Secara umum kepemimpinan berarti kemampuan dan kesiapan yang dimiliki seseorang untuk dapat mempengaruhi, mendorong, mengajak, menggerakkan, dan mengarahkan anggota untuk bias berbuat dalam rangka mendapat suatu tujuan tertentu yang telah ditetapkan.

Kemampuan yang harus dimiliki oleh seorang kepala sekolah untuk dapat menggerakkan seluruh sumber daya sekolah yang ada agar mau bekerjasama dalam mencapai tujuan sekolah yang telah ditetapkan. Kepala sekolah merupakan salah satu komponen pendidikan yang paling berperan dalam meningkatkan kualitas pendidikan, karena kepala sekolah adalah pengelola pendidikan pada satuan pendidikan atau pada tingkat sekolah. Jika kompetensi tersebut dikaitkan dengan kepala sekolah berarti kemampuan, keterampilan, dan kecakapan yang harus dimiliki dan dikuasai oleh seorang kepala sekolah untuk dapat melaksanakan tugas sebagai pengelola satuan pendidikan di tingkat satuan pendidikan.

\section{Identifikasi Masalah}

Aktualisasi mutu pendidikan yang diwujudkan oleh Kepala Sekolah dan para guru dalam melaksanakan tugasnya, antara lain juga dipengaruhi oleh latar belakang pendidikan, kompetensi kepemimpinan kompetensi guru, wawasan, pengetahuan, pengalaman masa kerja, lingkungan kerja dan beban tugasnya. Dalam pembahasan ini maka penulis akan mengidentifikasi masalah sebagai berikut :

1. Bagaimanakah kompetensi supervisi kepala sekolah yang dilaksanakan oleh pimpinan Sekolah Menengah Atas (SMA) 1926 Tangerang Selatan?

2. Bagaimanakah usaha kepala sekolah dan guru dalam rangka meningkatkan mutu pendidikan di Sekolah Menengah Atas (SMA) 1926 Tangerang Selatan?

3. Bagaimanakah Kompetensi supervisi kepala sekolah dan kompetensi profesional guru di Sekolah Menengah Atas (SMA) 1926 Tangerang Selatan?

4. Bagaimanakah Kompetensi Supervisi Kepala Sekolah dan Kompetensi Profesional Guru secara bersama-sama berpengaruh terhadap peningkatan mutu pendidikan?

5. Bagaimanakah peningkatan mutu dan kompetensi kepala sekolah serta Guru di Sekolah Menengah Atas (SMA) 1926 Tangerang Selatan?

6. Bagaimanakah Pengaruh kompetensi Supervisi Kepala Sekolah dan Kompetensi Profesional Guru terhadap peningkatan mutu secara persial?

7. Bagaimanakah Pengaruh Kompetensi Supervisi Kepala Sekolah dan Kompetensi Profesional Guru terhadap peningkatan mutu secara bersama-sama?

\section{Pembatasan Masalah}

Untuk memudahkan dalam pelaksanaan penelitian dan agar penelitian dapat terpusat kepada permasalahan maka penulis membatasi masalah sebagai berikut :

1. Kompetensi Supervisi Kepala Sekolah berpengaruh terhadap mutu pendidikan di Sekolah Menengah Atas (SMA) 1926 Tangerang Selatan.

2. Kompetensi Profesional Guru berpengaruh terhadap mutu pendidikan di Sekolah Menengah Atas (SMA) 1926 Tangerang Selatan.

3. Kompetensi Supervisi Kepala Sekolah dan Kompetensi Profesional Guru bersama-sama berpengaruh terhadap kinerja guru di Sekolah Menengah Atas (SMA) 1926 Tangerang Selatan. 


\section{Perumusan Masalah}

Berdasarkan pada identifikasi masalah dan pembatasan masalah maka penulis membuat rumusan masalah sebagai berikut :

1. Apakah terdapat pengaruh Kompetensi Supervisi kepala Sekolah terhadap Mutu Pendidikan di SMA 1926 Tangerang Selatan?

2. Apakah terdapat pengaruh Kompetensi Profesional Guru terhadap Mutu Pendidikan di SMA 1926 Tangerang Selatan?

3. Apakah terdapat pengaruh Kompetensi Supervisi Kepala Sekolah dan Kompetensi Profesional Guru bersama-sama terhadap Mutu Pendidikan di SMA 1926 Tangerang Selatan? Proses pendidikan yang bermutu ditentukan oleh berbagai unsur dinamis yang akan ada di dalam sekolah itu dan lingkungannya sebagai suatu kesatuan sistem. Menurut Townsend dan Butterworth (1992:35) dalam bukunya Your Child's School, ada sepuluh faktor penentu terwujudnya proses pendidikan yang bermutu, yakni :

a. Keefektifan kepemimpinan kepala sekolah;

b. Partisipasi dan rasa tanggung jawab guru dan staf;

c. Proses belajar mengajar yang efektif;

d. Pengembangan staf yang terprogram;

e. Kurikulum yang relevan;

f. Memiliki visi dan misi yang jelas;

g. Iklim sekolah yang kondusif;

h. Penilaian diri terhadap kekuatan dan kelemahan;

i. Komunikasi efektif baik internal maupun eksternal; dan

j. Keterlibatan orang tua dan masyarakat secara intrinsik.

Supriadi (2002:17) mengatakan : "orang yang mendalami teori difusi inovasi akan segera tahu bahwa setiap perubahan atau inovasi dalam bidang apapun, termasuk dalam pendidikan, memerlukan tahap-tahap yang dirancang dengan benar sejak ide dikembangkan hingga dilaksanakan“. Sejak awal, berbagai kondisi perlu diperhitungkan, mulai substansi inovasi itu sendiri sampai kondisi-kondisi lokal tempat inovasi itu akan diimplementasikan.

Intinya, suatu perubahan yang mendasar, melibatkan banyak pihak, dan dengan skala yang luas akan selalu memerlukan waktu. Suatu inovasi mestinya jelas kriterianya, terukur dan realistik dalam sasarannya, dan dirasakan manfaatnya oleh pihak yang melaksanakannya.

menurut (Hasibuan, 2001:167) adalah "Kepemimpinan adalah cara seorang pemimpin mempengaruhi perilaku bawahan, agar mau bekerja sama dan bekerja secara produktif untuk mencapai tujuan organisasi”.

Ada tiga syarat yang harus dipenuhi untuk menjadi kepala sekolah yaitu :

1. Aspek Akseptabilitas, Akseptabilitas adalah aspek mengandalkan dukungan riil dari komunitas yang dipimpinnya. Seorang kepala sekolah harus mendapat dukungan dari guru-guru dan karyawan lembaga yang bersangkutan sebagai komunitas formal yang dipimpinnya.

2. Aspek kapabilitas, Aspek kapabilitas menyangkut kompetensi (kemampuan) untuk menjalankan kepemimpinan. Untuk menjadi kepala sekolah tidak hanya cukup mendapat pengakuan dari guru-guru sebagai pendukungnya tapi juga harus memiliki kemampuan memimpin.

3. Aspek integritas, Aspek integritas adalah sebuah persyaratan yang sempurna apabila aspek akseptabilitas dan kapabilitas terpenuhi. Dengan persyaratan ini seroang kepala sekolah dapat menghasilkan produk kepemimpinan yang sempurna dan diterima oleh khalayak.

Supervisi berasal dari dua kata bahasa Inggris, yaitu super dan vision. Super berarti diatas dan vision berarti melihat, masih serumpun dengan inspeksi, pemeriksaan dan pengawasan, dan penilikan, dalam arti kegiatan yang dilakukan oleh atasan-orang yang berposisi diatas, pimpinan-terhadap hal-hal yang ada di bawahnya.

Wilem Mantja (2007) mengatakan bahwa, supervisi diartikan sebagai kegiatan supervisor (jabatan resmi) yang dilakukan untuk perbaikan proses belajar mengajar (PBM). Ada dua tujuan (tujuan ganda) yang harus diwujudkan oleh supervisi, yaitu : perbaikan (guru murid) dan peningkatan mutu pendidikan.

Tujuan umum Supervisi adalah memberikan 
bantuan teknis dan bimbingan kepada guru dan staf agar personil tersebut mampu meningkatkan kwalitas kinerjanya, dalam melaksanakan tugas dan melaksanakan proses belajar mengajar.

Secara operasional dapat dikemukakan beberapa tujuan konkrit dari supervisi pendidikan yaitu :

1. Meningkatkan mutu kinerja guru

a. Membantu guru dalam memahami tujuan pendidikan dan apa peran sekolah dalam mencapai tujuan tersebut.

b. Membantu guru dalam melihat secara lebih jelas dalam memahami keadaan dan kebutuhan siswanya.

c. Membentuk moral kelompok yang kuat dan mempersatukan guru dalam satu tim yang efektif, bekerjasama secara akrab dan bersahabat serta saling menghargai satu dengan lainnya.

d. Meningkatkan kualitas pembelajaran yang pada akhirnya meningkatkan hasil pembelajar siswa.

e. Meningkatkan kualitas pengajaran guru baik itu dari segi strategi, keahlian dan alat pengajaran.

f. Menyediakan sebuah sistim yang berupa penggunaan teknologi yang dapat membantu guru dalam pengajaran.

g. Sebagai salah satu dasar pengambilan keptusuan bagi kepala sekolah untuk reposisi guru.

2. Meningkatkan keefektifan kurikulum sehingga berdaya guna dan terlaksana dengan baik.

3. Meningkatkan keefektifan dan keefesiensian sarana dan prasarana yang ada untuk dikelola dan dimanfaatkan dengan baik sehingga mampu mengoptimalkan keberhasilan siswa.

4. Meningkatkan kualitas pengelolaan sekolah khususnya dalam mendukung terciptanya suasana kerja yang optimal yang selanjutnya siswa dapat mencapai hasil pembelajar sebagaimana yang diharapkan.

5. Meningkatkan kualitas situasi umum sekolah sehingga tercipta situasi yang tenang dan tentram serta kondusif yang akan meningkatkan kualitas pembelajaran yang me- nunjukkan keberhasilan lulusan.

Profesionalisme berasal dari istilah profesional yang dasar katanya adalah profesi (profession). Untuk itu ada baiknya penulis kemukakan terlebih dahulu istilah profesional. Profesional berarti persyaratan yang memadai sebagai suatu profesi (Abin Syamsuddin, 1996:48). Selain itu pengertian profesional menurut Tilaar (1999) bermakna : (1) sesuatu yang bersangkutan dengan profesi. (2) memerlukan kepandaian khusus untuk menjalankannya, (3) mengharuskan adanya pembayaran untuk melakukannya (lawan amatir).

Menurut Dedi Supriyadi (1998:95) dan Sudarwan Danim (2002:22), kata profesional merujuk pada dua hal: Pertama, adalah orang yang menyandang suatu profesi, orang yang biasanya melakukan pekerjaan secara otonom dan dia mengabdi diri pada pengguna jasa disertai rasa tanggung jawab atas kemampuan profesionalnya, atau penampilan seseorang yang sesuai dengan ketentuan profesi. Kedua, adalah kinerja atau performance seseorang dalam melakukan pekerjaan yang sesuai dengan profesinya. Pada tingkat tinggi, kinerja itu dimuati unsur-unsur kiat atau seni (art) yang menjadi ciri tampilan profesional seorang penyandang profesi.

Sebagaimana dinyatakan oleh (Oemar Hamalik, 2006:42) bahwa profesionalisme guru mengandung pengertian yang meliputi unsurunsur kepribadian, keilmuan, dan keterampilan. Dengan demikian dapat diartikan, bahwa kompetensi professional tentu saja meliputi ketiga unsur itu walaupun tekanan yang lebih besar terletak pada unsur keterampilan sesuai dengan peranan yang dikerjakan. Sehingga Danim (2002) menyatakn bahwa "orang yang profesional memiliki sifat-sifat yang berbeda dengan orang yang tidak profesional meskipun dalam pekerjaan yang sama atau katakanlah berada dalam satu ruang kerja."

Untuk mencapai derajat profesionalisme yang tinggi, maka dibutuhkan proses profesionalisasi. Adapun profesionalisasi dimaknai sebagai suatu proses untuk menjadikan suatu pekerjaan memperoleh status profesional. (Sudarwan Danim, 2002:23) menyatakan bahwa : "profesionalisasi adalah suatu proses peningkatan kualifikasi atau 
kemampuan para anggota penyandang suatu profesi untuk mencapai kriteria standar ideal dari penampilan atau perbuatan yang diinginkan oleh profesi itu.“

\section{METODE}

Metode penelitian ini adalah penelitian deskriptif. Populasi dalam penelitian ini seluruh guru SMA 1926 Negeri Pamulang, yang berjumlah 24 orang dari 34 SMA 1926 Negeri di Pamulang. Sampel diambil dengan menggunakan teknik cluster random sampling dengan cara pengelompokkan tingkat ekonomi masyarakat yaitu tingkat ekonomi tinggi, tingkat ekonomi sedang, dan tngkat ekonomi rendah.

Alat pengumpulan data yang digunakan adalah angket model skala likert dengan alternatif jawaban yaitu Sangat Mampu (5), Mampu (4), Kurang Mampu (3), Tidak Mampu (2), Sangat Tidak Mampu (1)). Jenis data dalam penelitian ini adalah data primer yang artinya data diperoleh langsung dari reponden, Dalam penulisan Tesis ini, penulis menggunakan metode penelitian Deskriptif.

Menurut H. Hadari Nawawi (1985:54) mengemukakan bahwa : "Metode deskriptif dapat diartikan sebagai prosedur pemecahan masalah yang diselidiki dengan menggambarkan atau melukiskan keadaan atau subyek/obyek penelitian penelitian pada saat sekarang berdasarkan faktafakta yang sebagaimana adanya." Arikunto (1998:114) menyatakan bahwa populasi adalah keseluruhan obyek penelitian, apabila seseorang ingin meneliti semua elemen yang ada dalam wilayah penelitian maka penelitiannya merupakan penelitian populasi.

Sugiyono (2001:57) menyatakan bahwa yang dimaksud dengan populasi adalah wilayah generalisasi yang terdiri atas objek/subjek yang mempunyai kuantitas dan karakteristik tertentu yang ditetapkan oleh peneliti untuk dipelajari kemudian ditarik kesimpulan.

Irawan, Prasetya (2000:72) menyatakan bahwa yang dimaksud dengan populasi adalah keseluruhan elemen yang akan dijelaskan oleh seorang peneliti di dalam penelitiannya. Populasi bisa berwujud air, udara, wilayah, sistem, dokumen, dan tentu saja manusia. Dengan demikian populasi adalah keseluruhan objek penelitian yang terdiri atas subjek/objek yang memiliki ciriciri/karakteristik yang ditetapkan oleh peneliti. Bertolak dari pengertian populasi diatas, maka yang dimaksud dengan populasi dalam penelitian ini adalah keseluruhan guru dan pegawai Sekolah Menengah Atas (SMA) 1926 Tangerang Selatan.

Adapun populasi dalam penelitian ini adalah seluruh Guru dan Pegawai pada Sekolah Menengah Atas (SMA) 1926 Tangerang Selatan. Berdasarkan data yang diperoleh dari Tata Usaha Sekolah, diketahui jumlah guru dan tata usaha Sekolah Menengah Atas (SMA) 1926 Tangerang Selatan hanya berjumlah 24 orang, maka seluruh guru dan tata usaha Sekolah Menengah Atas (SMA) 1926 Tangerang Selatan dijadikan sampel dalam penelitian ini.

Menurut Arikunto (1998:114) yang dimaksud dengan sumber data adalah "subyek darimana data diperoleh". Lebih lanjut Arikunto (1998:114) membagi sumber data sebagai berikut :

1. Person, adalah sumber data berupa orang yang bisa memberikan data berupa jawaban lisan melalui wawancara atau tertulis melalui angket.

2. Place, adalah sumber data berupa tempat yang menyajikan tampilan berupa keadaan diam atau bergerak. Keduanya merupakan obyek untuk penggunaan metode observasi.

3. Paper, adalah sumber data berupa simbol yang menyajikan tanda-tanda berupa huruf, angka, gambar, atau simbol-simbol lain.

Pengumpulan data penelitian dilakukan dengan menggunakan teknik sebagai berikut :

1. Data primer

Yaitu sumber data yang berasal dari komunikasi secara langsung dengan responden baik secara tertulis. Dalam hal ini peneliti menggunakan kuesioner.

Muhammad Musa dan Titi Nurfitri (1988:39) menyatakan bahwa data primer adalah data yang dikumpulkan dari tangan pertama dan diolah oleh suatu organisasi dan perorangan."

Sedangkan menurut Moleong (2001:112) 
bahwa; kata-kata dan tindakan orang-orang yang diamati dan diwawancarai merupakan sumber utama. Sumber data utama dicatat melalui catatan tertulis atau melalui perekaman video/audio tape, pengambilan foto, atau film.

2. Data sekunder

Yaitu sumber data yang berfungsi sebagai pelengkap yang biasa diperoleh dari berbagai sumber, seperti arsip-arsip serta dokumen yang menunjang penelitian.

Menurut Musa dan TitiNurfitri (1988:39) data sekunder adalah data yang diperoleh dari suatu organisasi atau perusahan yang berasal dari pihak lain yang telah mengumpulkan dan mengolahnya. Data sekunder diperoleh secara tidak langsung dari objek yang diteliti.

Nazir (1998:211) mengemukakan bahwa "Pengumpulan data adalah suatu proses pengadaan data primer untuk keperluan penelitian“. Pengumpulan data merupakan langkah yang amat penting dalam metode penelitian, peneliti menggunakan teknikteknik pengumpulan secara dokumentasi, observasi, wawancara dan dokumentasi.

1. Dokumentasi

Arikunto (1998:236) menyatakan bahwa tidak kalah penting dari metode-metode lain, adalah metode dokumentasi, yaitu mencari data mengenai hal-hal atau variabel yang berupa catatan, transkrip, buku, surat, majalah, prasasti, notulen, rapat, legger, agenda dan sebagainya.

Teknik ini memiliki kelebihan dibandingkan metode lain dimana data yang diperoleh bersifat tetap atau permanen, sehingga apabila terjadi kekeliruan dalam proses penelitian dapat dilakukan pengecekan secara mudah.

2. Kuesioner

Teknik pengumpulan data yang dilakukan dengan cara menggunakan daftar pertanyaan yang telah disusun sedemikian rupa dan dijawab oleh responden. Kuisioner disebarkan kepada sejumlah sampel guru Sekolah Menengah Atas (SMA) 1926 Tangerang Selatan

\section{Teknik Analisa Data}

Penelitian ini menggunakan pendekatan regresi, dengan maksud untuk mengetahui kompetensi supervisi kepala sekolah dan kompetensi profesional guru terhadap kinerja di Sekolah Menengah Atas (SMA) 1926 Tangerang Selatan.

Dalam penelitian ini, menekankan pada analisis. Adapun metode analisis data yang digunakan adalah (Suharsimi Arikunto. 2002: dan Sugiyanto, 2002) : Metode Deskriptif dan Metode Kuantitatif.

1. Menggunakan data kuantitatif untuk menganalisa Kompetensi supervisi kepala sekolah dan kompetensi profesional guru terhadap mutu pendidikan di Sekolah Menengah Atas (SMA) 1926 Tangerang Selatan dari semua frekuensi data yang masuk. Data ini adalah data kualitatif yang diangkakan dalam bentuk skorsing mengacu pada skala likert. Pada skala ini menggunakan hanya item yang secara pasti baik dan secara pasti buruk. Skor responsi responden dijumlahkan dan jumlah ini merupakan total skor, dan total skor inilah ditafsirkan sebagai posisi responden. Data yang terkumpul melalui kuesioner ini diberi nilai dengan menerapkan skala likert 1 satu) sampai dengan 5 (lima). Data pernyataan responden yang masuk berdasarkan pilihan jawaban dari 1 (satu) sampai 5 (lima). Setiap angka menunjukkan kategori tingkat persetujuan, angka 1 (satu) menyatakan sangat tidak setuju dan angka 5 (lima) menyatakan sangat setuju. Dalam mendeskripsikan hasil penelitian, maka ditentukan lima kelas atau kategori skor. Untuk menentukan kategori ini digunakan rumus sebagai berikut :

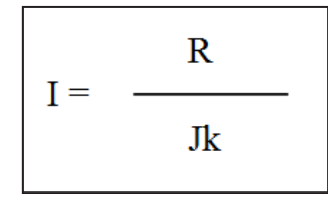

Dimana :

$\mathrm{I}=$ Interval

$\mathrm{R}=$ Jarak pengukuran (kemungkinan jumlah skor tertinggi dikurangi jumlah skor terendah)

$\mathrm{Jk}=$ Jumlah jarak kelas 
Dengan demikian untuk variabel bebas yaitu kompetensi supervisi kepala sekolah dan kompetensi profesional guru, variabel terikat yaitu peningkatan mutu, maka kemungkinan skor yang tertinggi adalah 5 (lima) dan kemungkinan skor terendah 1 (satu) serta jumlah jarak kelas adalah 5 (lima), maka interval kelas dapat ditentukan sebagai berikut (Sugiyono, 2002) :

$\mathrm{I}=\frac{\mathrm{R}}{\mathrm{Jk}}=\frac{5-1}{5}=0,8$

Berdasarkan interval tersebut, maka dapat ditentukan ukuran atau kategori skor, tabel 3.2 sebagai berikut :

\begin{tabular}{|c|c|}
\hline \multicolumn{2}{|c|}{ Tabel 3.2. Skor dan Tafsirannya } \\
\hline Nilai skor & Tafsirannya \\
\hline Nilai skor $1+<1,7$ & Katagori sangat rendah \\
\hline Nilai skor $1,8+<2,5$ & Katagori rendah \\
\hline Nilai skor $2,6+<3,3$ & Katagori cukup \\
\hline Nilai skor $3,4+<4,1$ & Katagori tinggi \\
\hline Nilai skor $4,2+<5$ & Katagori sangat tinggi \\
\hline & Sumber : olahan skor \\
\hline
\end{tabular}

2. Uji reliabilitas instrumen dengan realibility analisis untuk mendapat besaran conbrach alpha dan uji validitas atau dengan korelasi pearson productmoment. Uji ini untuk melihat apakah instrumen dan butir pernyataan atau pernyataan reliable dan valid (Imam Ghozali, 2005).

3. Uji Normalitas dilakukan untuk mengetahui apakah data tersebut berdistribusi normal dengan melihat grafik.

4. Regresi dan korelasi keduanya mempunyai pengaruh, dan atau hubungan yang sangat erat. Setiap regresi pasti ada korelasi yang tidak dilanjutkan dengan regresi, adalah korelasi antara dua atau lebih variabel yang tidak mempunyai hubungan kausal/sebab akibat, atau hubungan fungsional. Analisis regresi dilakukan bila hubungan dua atau lebih variabel berupa hubungan sebab akibat/ kausal. Kompetensi supervisi kepala sekolah dan kompetensi profesional guru terhadap peningkatan mutu pendidikan di Sekolah Menengah Atas (SMA) 1926 Tangerang
Selatan dapat dikatakan hubungan yang fungsional untuk ini menggunakan regresi berganda. Penelitian ini dilakukan untuk mengetahui pengaruh kompetensi supervisi kepala sekolah dan kompetensi profesional guru terhadap peningkatan mutu pendidikan di Sekolah Menengah Atas (SMA) 1926 Tangerang Selatan untuk melihat pengaruh masing-masing variabel independent (bebas) terhadap variabel dependent (terikat) menggunakan regresi sederhana sebagai berikut :

$$
y=a+b x
$$

Untuk melihat hubungan, maka dihitung koefisien korelasinya dengan rumus di bawah ini :

$$
r X i Y i=\frac{n \sum X i, Y i-\left(\sum X i\right)\left(\sum Y i\right)}{\sqrt{\left(n \sum X i^{2}-\left(\sum x i\right)^{2}\right\}\left\{n \sum Y i^{2}-\left(\sum Y\right)^{2}\right\}}}
$$

Untuk diketahui apakah koefisien korelasi yang didapat ada artinya perlu diadakan pengujian statistik F dengan rumus sebagai berikut :

$\mathrm{R}^{2}=$ Koefisien korelasi $(\mathrm{r})$

$\mathrm{K}=$ Jumlah variabel independent

$\mathrm{n} \quad=$ Jumlah anggota sampel

Jika ternyata perhitungan $\mathrm{F}>F_{\text {tabel }}$ maka terdapat hubungan yang sangat erat antara variabel dependent harus dihitung korelasi ganda. Korelasi ganda bukan merupakan penjumlahan korelasi product moment sederhana antara satu variabel independent dengan variabel dependent melainkan dengan rumus tersendiri. Korelasi ganda (r) merupakan angka yang menunjukkan arah dan kuatnya hubungan antara dua atau lebih variabel independent secara bersama-sama terhadap variabel dependent.

Pengujian signifikasi terhadap koefisien korelasi product moment sederhana dapat menggunakan rumus berikut : Nilai koefisien korelasi r berkisar antara -1 sampai +1 yang kriteria pemanfaatnnya sebagai berikut :

1) Jika nilai $r>0$ artinya makin besar nilai variabel X (independent/bebas), makin besar pula nilai variabel $\mathrm{Y}$ (dependent/bebas), makin besar pula nilai variabel Y (dependent/ terikat) atau sebaliknya.

2) Jika nilai $r<0$ artinya telah terjadi hubungan 
yang linier negative, yaitu makin kecil nilai variabel X (independent), maka makin besar nilai variabel $Y$ (dependent) atau sebaliknya.

3) Jika nilai $r=0$ artinya tidak ada hubungan sama sekali antara variabel (indevendent) atau sebaliknya.

4) Jika nilair $=1$ atau $\mathrm{r}=-1$ telah terjadi hubungan linier sempurna yaitu garis lurus, sedangkan untuk nilai $r$ yang makin mengarah ke angka 0 maka garis makin lurus.

5) Pengujian $r$ dengan $r$ tabel mengacu pada tingkat signifikan ( $\square$ ) $5 \%$ dan $1 \%$. Sedangkan arti harga $r$ akan dikonsultasikan dengan tabel 3.3 interprestasi nilai $r$ sebagai berikut :

\begin{tabular}{|c|c|}
\hline \multicolumn{2}{|c|}{ Tabel 3.3. Interpretasi Koefisien Korelasi } \\
\hline Interval Koefisien & Tingkat Hubungan \\
\hline$+0,00+0,199$ & Sangat rendah \\
\hline$+0,20+0,399$ & Rendah \\
\hline$+0,40+0,599$ & Cukup kuat \\
\hline$+0,60+0,799$ & Kuat \\
\hline$+0,80+1,000$ & Sangat kuat \\
\hline
\end{tabular}

6) Untuk diketahui apakah korelas $r$ yang didapat ada artinya perlu diadakan pengujian statistik $\mathrm{t}$ dengan rumus sebagai berikut :

$$
T=\frac{r \sqrt{(N-2)}}{\sqrt{(1-r)^{2}}}
$$

7) Untuk mengetahui besarnya hubungan dan pengaruhnya secara parsial atau bersamasama antara kompetensi supervisi kepala sekolah dan kompetensi professional guru terhadap mutu pendidikan di Sekolah Menengah Atas (SMA) 1926 Tangerang Selatan dihitung dengan menghitung Koefisien Determinasi (KD) dengan rumus sebagai berikut :

$$
\mathrm{KD}=\mathrm{r}^{2} \mathrm{X} 100 \%
$$

Persamaan regresi untuk tiga prediktor adalah :

$$
\mathrm{Y}=\mathrm{a}+\mathrm{b}_{1} \mathrm{X}_{1}+\mathrm{b}_{2} \mathrm{X}_{2}+\ldots \ldots+\mathrm{b}_{\mathrm{n}} \mathrm{X}_{\mathrm{n}}
$$

Uji signifikan koefisien regresi ganda adalah sebagai berikut :

$$
F=\frac{R^{2}(n-m-1)}{M\left(-R^{2}\right)}
$$

$\mathrm{n} \quad=$ jumlah responden

$\mathrm{m}=$ jumlah variabel

Jika dihitung $\mathrm{F}>\mathrm{F}_{\text {tabel }}$ maka regresi ganda yang diuji signifikan, yaitu dapat diberlakukan ke populasi dengan taraf kesalahan $5 \%$ atau $1 \%$.

Guna mempercepat seluruh perhitungan diatas, maka digunakan program statistik dengan Statistik program For Social Science (SPSS). Dari pengolahan data dengan SPSS maka diperoleh hasil sebagai berikut :

1. Uji reliabilitas instrument, uji validitas dan normalitas data.

2. Korelasi, ukuran lain dan analisisnya

3. Persamaan regresi dan analisisnya

4. Lain-lain yang dibutuhkan

\section{HASIL dan PEMBAHASAN}

Hasil penelitian ini menguraikan deskripsi data mengenai persepsi guru tentang kompetensi supervisi kepala sekolah SMA 1926 Negeri Pamulang dalam merencanakan program supervisi akademik, melaksanakan supervisi akademik dengan menggunakan pendekatan dan teknik yang tepat, dan menindaklanjuti hasil supervisi akademik. Persepsi guru tentang kompetensi supervisi kepala sekolah SMA 1926 dalam merencanakan program supervisi.

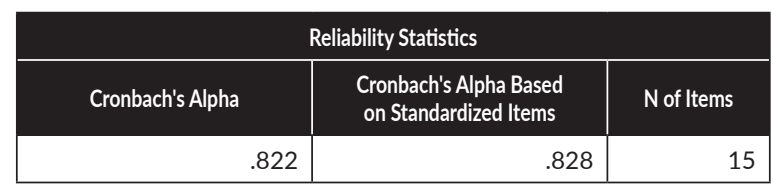

Dari tabel Reliability Statistics diatas didapat koefisisen reliabilitas (Cronbach's Alpha) sebesar 0,822 lebih besar dari 0,6 berarti instrument yang di uji reliable dengan jumlah pertanyaan 15 .

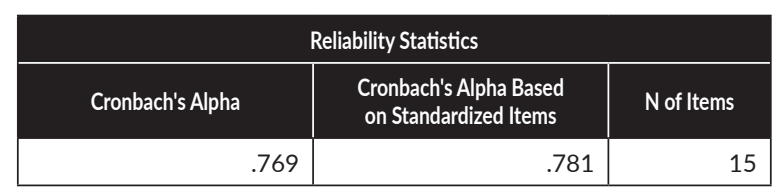


Dari tabel Reliability Statistics diatas didapat koefisisen reliabilitas (Cronbach's Alpha) sebesar 0,769 lebih besar dari 0,6 berarti instrument yang di uji reliable dengan jumlah pernyataan 15 .

\begin{tabular}{r|r|r|}
\multicolumn{3}{|c|}{ Reliability Statistics } \\
\hline \multicolumn{1}{|r|}{ Cronbach's Alpha } & $\begin{array}{c}\text { Cronbach's Alpha Based } \\
\text { on Standardized Items }\end{array}$ & \multicolumn{1}{c|}{ N of Items } \\
\hline .706 & .712 & 15 \\
\hline
\end{tabular}

Dari tabel Reliability Statistics diatas didapat koefisisen reliabilitas (Cronbach's Alpha) sebesar 0,706 lébih bes'ar dari 0,6 berarti instrument yang di uji reliable dengan jumlah pernyataan 15.
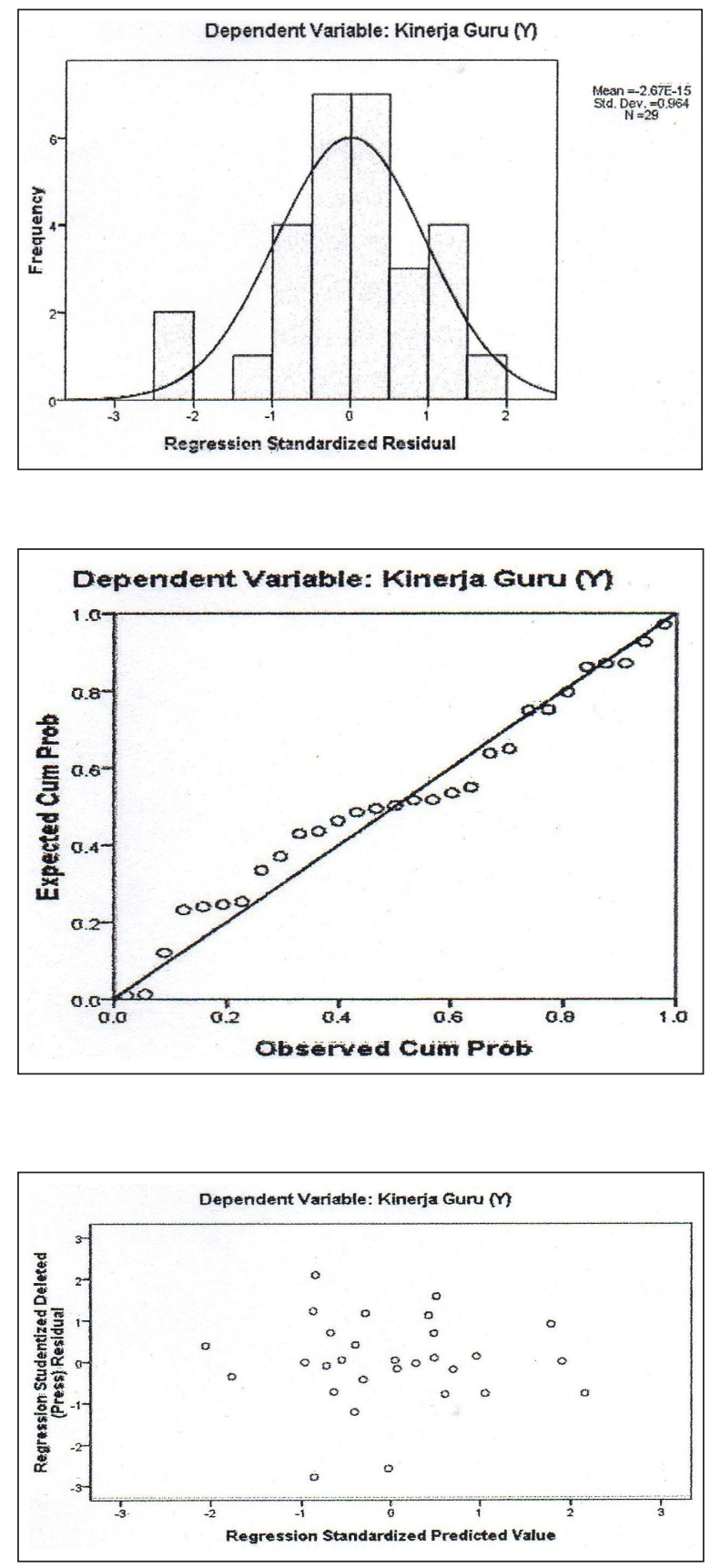

Salah satu cara termudah untuk melihat normalitas adalah melihat histogram yang membandingkan antara data ebservasi dengan distribusi yang mendekati distribusi normal. Namun demikian dengan hanya melihat histogram bisa menyesatkan khususnya untuk jumlah yang kecil.

Metode normal probability plot yang membandingkan distribusi kumuulatif dari data sesungguhnya dengan distribusi kumulatif dari distribusi normal, untuk itu dapat dijelaskan sebagai berikut :

Dengan melihat tampilan, grafik histogram memberikan pola distribusi yang mendekati normal. Sedangkan pada grafik normal plot terlihat titik-titik menyebar disekitar garis diagonal, serta penyebarannya mengikuti arah garis diagonal. Kedua grafik tersebut menunjukkan bahwa model regresi layak dipakai karena memenuhi asurnsi normalitas.

\begin{tabular}{|l|r|r|r|}
\hline \multicolumn{4}{|c|}{ Descriptive Statistics } \\
\hline & Mean & Std. Deviation & \multicolumn{1}{c|}{ N } \\
\hline Kinerja Guru & 58.7241 & 5.21602 & 29 \\
\hline Supervisi Kepala Sekolah & 56.9310 & 6.24460 & 29 \\
\hline Kompetensi Profesional Guru & 57.6897 & 5.58764 & 29 \\
\hline \multicolumn{3}{|c|}{ Sumber: SPSS 16} \\
\hline
\end{tabular}

Kinerja guru, berdasarkan sumber olahan data diatas terlihat persepsi responden terhadap variabel kinerja guru sangat tinggi, yakni nilai skor berkisar antara 3.4 4.2. Artinya responden menganggap kinerja pegawai baik dengan skor 58.7241 dengan.

Supervisi Kepala Sekolah, berdasarkan sumber olahan data diatas terlihat persepsi responden terhadap variabel Supervisi Kepala Sekolah sangat tinggi, yakni nilai skor berkisar antara 3.4 4.2. Artinya responden menganggap Supervisi Kepala Sekolah baik dengan skor 56.9310 .

Kompetensi profesional guru, berdasarkan sumber olahan data diatas terlihat persepsi responden terhadap variable Kompetensi Profesional Guru tinggi, yakni nilai skor berkisar antara 3.4 4.2. Artinya responden menganggap Kompetensi profesional guru dengan skor 57.6897, dengan N adalah jumlah responden sebanyak 29 . 


\begin{tabular}{|l|r|r|r|r|}
\hline \multicolumn{7}{|c|}{ Model Summary $^{\mathrm{b}}$} \\
\hline \multicolumn{1}{|c|}{ Model } & \multicolumn{1}{|c|}{$\mathrm{R}$} & $\mathrm{R}$ Square & $\begin{array}{l}\text { Adjusted R } \\
\text { Square }\end{array}$ & $\begin{array}{r}\text { Std. Error of } \\
\text { the Estimate }\end{array}$ \\
\hline 1 & $.160^{\mathrm{a}}$ & .025 & .011 & 5.24366 \\
\hline $\begin{array}{l}\text { a. Predicators : (Constant), SUPERVISI KEPALA SEKOLAH } \\
\text { b. Dependent Variable: KINERJA GURU }\end{array}$ \\
\hline
\end{tabular}

Dengan melihat tabel di atas, angka Square adalah 0.025. Square bisa disebut koefesien detenninasi yang dalam hal ini berarti 2.50 variabel kinerja Guru dijelaskan/dipengaruhi oleh variable Supervisi Kepala Sekolahsedangkan sisanya (100\% 2.50\%597,50\%) dijelaskan oleh sebab-sebab lain. Square berkisar pada angka 0 s/d 1, dengan catatan semakin kecil angka Square, semakin lemah hubungan kedua variabel.

\begin{tabular}{|c|c|c|c|c|c|}
\hline \multicolumn{6}{|c|}{ Coefficients ${ }^{a}$} \\
\hline \multirow[b]{2}{*}{ Model } & \multicolumn{2}{|c|}{$\begin{array}{c}\text { Unstandardized } \\
\text { Coefficients }\end{array}$} & \multicolumn{3}{|c|}{ Standardized Coefficients } \\
\hline & B & Std. Error & Beta & $\mathrm{t}$ & Sig. \\
\hline 1 (Constant) & 66.313 & 9.087 & & 7.298 & .000 \\
\hline $\begin{array}{l}\text { Supervisi } \\
\text { Kepala Sekolah }\end{array}$ & .133 & 159 & .160 & .840 & .408 \\
\hline a. Dependent Var & NERJA GL & & & & \\
\hline
\end{tabular}

Berdasarkan tabel diatas tersebut juga memperlihatkan gambaran persarnaan regresi sederhana sebagai berikut :

$$
\mathrm{Y}=66.313+0.133 \mathrm{X}_{1}
$$

Konstanta sebesar 66.313, menyatakan bahwa jika tidak ada variabel Supervisi Kepala Sekolah maka nilai variabel kinerja Guru sebesar 66.313. Koefesien regresi sebesar 0.133 menyatakan bahwa setiap penambahan nilai 1 satuan variabel supervisi kinerja Guru sebesar 0.133 satuan atau sebaliknya.

\begin{tabular}{|l|r|r|r|r|}
\hline \multicolumn{5}{|c|}{ Model Summary $^{\mathrm{b}}$} \\
\hline \multicolumn{1}{|c|}{ Model } & \multicolumn{1}{|c|}{$\mathrm{R}$} & $\mathrm{R}$ Square & $\begin{array}{c}\text { Adjusted R } \\
\text { Square }\end{array}$ & $\begin{array}{c}\text { Std. Error of } \\
\text { the Estimate }\end{array}$ \\
\hline 1 & $.262^{\mathrm{a}}$ & .068 & .034 & 5.12676 \\
\hline $\begin{array}{l}\text { a. Predicators : (Constant), KOMPETENSI PROFESIONAL GURU } \\
\text { b. Dependent Variable: KINERJA GURU }\end{array}$ \\
\hline
\end{tabular}

Dengan melihat tabel diatas, angka Square adalah 0.068 Square bisa disebut koefesien determinasi yang dalam hal ini berarti $6.80 \%$ variabel kinerja Guru dijelaskan/dipengaruhi oleh variabel Kompetensi Profesional Guru Sedangkan sisanya $(100 \%-6.80 \%=93.20 \%)$ dijelaskan oleh sebab-sebab lain. Square berkisar pada angka 0 s.d
1, dengan catatan semakin kecil angka R Square, semakin lemah hubungan kedua variabel.

\begin{tabular}{|l|r|r|r|r|c|}
\hline \multicolumn{1}{|c|}{ Coefficients $^{\mathrm{a}}$} \\
\hline \multirow{2}{*}{ Model } & \multicolumn{2}{|c|}{$\begin{array}{c}\text { Unstandardized } \\
\text { Coefficients }\end{array}$} & \multicolumn{3}{|c|}{ Standardized Coefficients } \\
\cline { 2 - 6 } & \multicolumn{1}{c|}{ B } & \multicolumn{1}{c|}{ Std. Error } & \multicolumn{1}{c|}{ Beta } & \multicolumn{1}{c|}{$\mathrm{t}$} & \multicolumn{1}{c|}{ Sig. } \\
\hline 1 (Constant) & 72.812 & 10.048 & & 7.246 & .000 \\
\hline $\begin{array}{l}\text { Kompetensi } \\
\text { Profesional Guru }\end{array}$ & .244 & .173 & .262 & 1.840 & .170 \\
\hline a. Dependent Variable: KINERJA GURU & & & & \\
\hline
\end{tabular}

Tabel di atas tersebut juga memperlihatkan gambaran persamaan regresi sederhana sebagai berikut:

\section{$72.8120 .244 \mathrm{X}_{3}$}

Konstanta sebesar 72.812, menyatakan bahwa jika tidak ada variabel Kompetensi Profesional Guru rnaka nilai variabel kinerja Gurusebesar 72.812. Koefesien regresi sebesar 0.244 menyatakan bahwa setiap penambahan nilai 1 satuan variabel Kompetensi Profesional Guru akan meningkatkan nilai variabel kinerja Guru sebesar 0.244 satuan atau sebaliknya.

\begin{tabular}{|l|r|r|r|r|}
\hline \multicolumn{7}{|c|}{ Model Summary $^{\mathrm{b}}$} \\
\hline \multicolumn{1}{|c|}{ Model } & \multicolumn{1}{c|}{ R } & \multicolumn{1}{c|}{ R Square } & $\begin{array}{c}\text { Adjusted R } \\
\text { Square }\end{array}$ & $\begin{array}{c}\text { Std. Error of } \\
\text { the Estimate }\end{array}$ \\
\hline 1 & $.328^{\mathrm{a}}$ & .108 & .039 & 5.11351 \\
\hline $\begin{array}{l}\text { a. Predicators : (Constant), SUPERVISI KEPALA SEKOLAH, } \\
\text { KOMPETENSI PROFESIONAL GURU }\end{array}$ \\
\hline
\end{tabular}

Tabel Variables Entered/Removed (b) menunjukkan bahwa tidak ada variabel yang dikeluarkan (removed) atau dengan kata lain ketiga variabel bebas dimasukkan dalam perhitungan regresi.

Angka Square adalah 0. 108. hal ini berarti $10.80 \%$ variable kinerja Guru dijelaskan/dipengaruh oleh variabel Supervisi Kepala Sekolah, Supervisi dan Kompetensi Profesional Guru sedangkan sisanya $(100 \%-10,80 \%=89,20 \%)$ dijelaskan oleh sebab-sebab lain.

R Square berkisar pada angka 0 s.d 1, dengan catatan semakin kecil angka $\mathrm{R}$ Square, semakin lemah hubungan kedua variabel. Artinya secara bersama-sama variable Supervisi Kepala Sekolah, Supervisi dan Kompetensi Profesional Guru sangat berpengaruh terhadap variabel Kinerja Guru. 


\begin{tabular}{|c|r|r|r|c|c|c|}
\hline \multicolumn{2}{|c|}{ Model } & $\begin{array}{c}\text { Sum of } \\
\text { Squares }\end{array}$ & df & $\begin{array}{c}\text { Mean } \\
\text { Square }\end{array}$ & F & Sig. \\
\hline 2 & Regression & 81.945 & 2 & 40.972 & 1.567 & $.228^{b}$ \\
\hline & Residual & 679.848 & 26 & 26.418 & & \\
\hline & Total & 761.793 & 28 & & & \\
\hline $\begin{array}{l}\text { a. Predicators: (COnstant), SUPERVISI KEPALA SEKOLAH, } \\
\text { KOMPETENSI PROFESIONAL GURU }\end{array}$ \\
\hline
\end{tabular}

Dari uji ANOVA didapat hitung sebesar 1.567 Pengujian satu variabel bebas $\mathrm{X}$ terhadap variable $\mathrm{Y}$ dilakukan dengan uji $\mathrm{F}$.

1) Menentukan tabel dan hitung.

tabel Tingkat sigrlifikansi 5\%

Degree of freedom (df)

Dari output komputer pada tabel ANOVA dan kolom df, didapat:

Numerator $=2$

Denumerator $=28$

Maka tabel untuk $(0.05 ; 2 ; 28)$ didapat 134 hitung

Dari output komputer pada kolom didapat hitung sebesar 1.567

\begin{tabular}{l|r|r|r|c|c|}
\hline \multicolumn{1}{|c|}{ Coefficients $^{\mathrm{a}}$} \\
\hline \multirow{2}{*}{ Model } & \multicolumn{2}{|c|}{$\begin{array}{l}\text { Unstandardized } \\
\text { Coefficients }\end{array}$} & \multicolumn{2}{|c|}{ Standardized Coefficients } \\
\cline { 2 - 6 } & \multicolumn{1}{c|}{$\mathrm{B}$} & Std. Error & \multicolumn{1}{c|}{ Beta } & \multicolumn{1}{c|}{$\mathrm{t}$} & \multicolumn{1}{c|}{ Sig. } \\
\hline 1 (Constant) & 83.804 & 14.368 & & 5.833 & .000 \\
\hline $\begin{array}{l}\text { Supervisi } \\
\text { Kepala Sekolah }\end{array}$ & .167 & .156 & .200 & 1.068 & .295 \\
\hline $\begin{array}{l}\text { Kompetensi } \\
\text { Profesional Guru }\end{array}$ & .270 & .175 & .289 & 1.547 & .134 \\
\hline a. Dependent Variable: KINERJA GURU \\
\hline
\end{tabular}

Tabel tersebut menggambark'an persamaan regresi sebagai berikut:

83.8040 .167 X1 0.270 X2

Dimana:

$\mathrm{Y}$ = Kinerja Guru

$\mathrm{X}_{1}=$ Supervisi Kepala Sekolah

$\mathrm{X}_{2}=$ Kompetensi Profesional Guru

Konstanta sebesar 83.804, menyatakan bahwa jika tidak ada variabel Supervisi Kepala Sekolah, dan Kompetensi Profesional Guru maka nilai variabel kinerja Guru sebesar 83.804.

Koefesien regresi $\mathrm{X}_{1}$ sebesar 0.167 menyatakan bahwa setiap pertambahan nilai 1 satuan variabel Supervisi Kepala Sekolah, dan Variabel lainnya tetap maka akan meningkatkan / menambah (+) nilai variabel kinerja Guru sebesar
0.167 satuan atau sebaliknya.

Dengan menggunakan kriteria yang sudah ditentukan, rata-rata skor yang diperoleh dari rekapitulasi menunjukkan bahwa kepala sekolah sudah memiliki kompetensi supervisi yang baik. Dalam data penelitian ini dapat disimpulkan bahwa kompetensi supervisi kepala sekolah SMA 1926 di Pamulang sudah dilaksanakan Dengan Baik.

\section{Pembahasan}

Hasil penelitian menunjukkan bahwa persepsi guru tentang kompetensi supervise kepala sekolah SMA 1926 Negeri Pamulang dalam kategori mampu dengan tingat capaian $80 \%$.

Hasil penelitian ini menunjukkan bahwa kepala sekolah sudah mampu dalam merencanakan program supervise akademik. Hal ini sesuai dengan Makawibang, Jerry (2012:80) mengemukakan bahwa kepala sekolah merencanakan program supervise sesuai dengan kebutuhan guru.

Merencanakan program supervisi akademik sesuai kebutuhan guru menentukan keberhasilan kegiatan supervise, karena supervisi yang dilakukan tidak terencana akan mengganggu pelaksanaan supervisi, dan supervise berjalan kurang maksimal.

Persepsi Guru tentang Kompetensi Supervisi Kepala sekolah dalam melaksanakan program supervisi dengan menggunakan pendekatan dan teknik yang tepat.

Agar terciptanya kegiatan belajar mengajar (KBM) berjalan dengan lancar dan sesuai dengan tujuan pendidikan maka diperlukan guru yang professional untuk meningkatkan profesionalisme guru maka kepala sekolah perlu melakukan supervisi.

Berdasarkan hasil penelitian diperoleh temuan bahwa persepsi guru tentang melaksanakan supervisi di SMA 1926 Negeri Pamulang sudah tergolong mampu dengan tingkat capaian $82.2 \%$.

Hal ini menunjukkan bahwa kepala sekolah sudah mampu dalam melaksanakan supervise. Menurut Makawibang, Jerry (2012:80) melaksanakan supervisi akademik sesuai dengan menggunakan pendekatan dan teknik yang tepat 
dalam meniongkatkan profesionalisme guru.

Persepsi Guru tentang Kompetensi Supervisi Kepala sekolah dalam menindaklanjuti hasil supervisi akademik dalam rangka penilngkatan profesionalisme guru

Kompetensi supervisi dalam hal menindaklanjuti hasil supervise masih tergolong cukup mampu. Hal ini terlihat dari tingkat capaian 78.2\%. Hasil ini menunjukkan bahwa kepala sekolah SMA 1926 Negeri Kecamatan Padang Timur dalam cukup mampu menindaklanjuti supervisi akademik.

Kepala sekolah dalam melakukan tindaklanjut dapat meningkatkan profesionalisme guru. Tindak lanjut dilakukan melalui hasil dari pelaksanaan supervisi. Dari hasil tersebut kepala sekolah melakukan tindak lanjut berupa seminar, pelatihan, dll. Hal ini sesuai dengan pendapat Makawibang, Jerry (2012:80) mengemukakan menindaklanjuti hasil supervisi melalui pengembangan professional guru, PTK, dll.

Tindak lanjut dilakukan dalam rangka memberikan langkah-langkah pembinaan dan menentukan apa program supervisi selanjutnya dimasa mendatang. Melaksanakan tindak lanjut kegiatan supervisi akan menjadilebih berfungsi dan lebih berarti dalam membawa suatu perubahan.

Uji reliabilitas instrumen dengan realibility analisis untuk mendapat besaran conbrach alpha dan uji validitas atau dengan korelasi pearson product moment. Uji ini untuk melihat apakah instrumen dan butir pernyataan atau pernyataan reliable dan valid (Imam Ghozali, 2005).

Uji Normalitas dilakukan untuk mengetahui apakah data tersebut berdistribusi normal dengan melihat grafik.

Regresi dan korelasi keduanya mempunyai pengaruh, dan atau hubungan yang sangat erat. Setiap regresi pasti ada korelasi yang tidak dilanjutkan dengan regresi, adalah korelasi antara dua atau lebih variabel yang tidak mempunyai hubungan kausal/sebab akibat, atau hubungan fungsional. Analisis regresi dilakukan bila hubungan dua atau lebih variabel berupa hubungan sebab akibat/kausal. Kompetensi supervisi kepala sekolah dan kompetensi profesional guru terhadap peningkatan mutu pendidikan di Sekolah Menengah Atas (SMA) 1926 Tangerang Selatan dapat dikatakan hubungan yang fungsional untuk ini menggunakan regresi berganda.

Penelitian ini dilakukan untuk mengetahui pengaruh kompetensi supervisi kepala sekolah dan kompetensi profesional guru terhadap peningkatan mutu pendidikan di Sekolah Menengah Atas (SMA) 1926 Tangerang Selatan untuk melihat pengaruh masing-masing variabel independent (bebas) terhadap variabel dependent (terikat) menggunakan regresi sederhana sebagai berikut :

$$
y=a+b x
$$

\section{SIMPULAN}

Berdasarkan analisis data hasil penelitian dari pembahasan diatas, dapat disimpulkan mengenai kompetensi supervisi kepala sekolah SMA 1926 Negeri di Pamulang.

Persepsi Guru terhadap Supervisi Kepala Sekolah tinggi yakni nilai skor berkisar 3.4 - 4.1 dengan skor rata-rata adalah sebesar 3.7954 artinya Guru menganggap Supervisi Kepala Sekolah yang diterimanya dari Sekolah Menengah Atas (SMA) 1926 Tangerang Selatan baik dan tinggi.

Persepsi Guru terhadap Kompetensi Profesional Guru tinggi yakni nilai skor berkisar 3.4 - 4.1 dengan skor rata-rata adalah sebesar 3.8460 artinya Guru menganggap Kompetensi Profesional Guru yang terjadi di Sekolah Menengah Atas (SMA) 1926 Tangerang Selatan baik dan tinggi.

Persepsi Guru terhadap kinerjanya tinggi yakni nilai skor berkisar 3.4 4.1 dengan skor rata-rata adalah sebesar 3,9375 artinya guru menganggap kinerjanya di Sekolah Menengah Atas (SMA) 1926 Tangerang Selatan baik dan tinggi.

Besar hubungan antara variable Supervisi Kepala Sekolah dengan variabel kinerja Gum yang dihitung dengan koefesien korelasi adalah 0,167 sehingga terjadi hubungan yang kuat dan positif. antara Supervisi Kepala Sekolah terhadap kinerja Guru. Apabila Supervisi Kepala Sekolah 
baik maka akan diikuti kenaikan tingkat kinerja Guru pada Sekolah: Menengah Atas (SMA) 1926 Tangerang Selatan. Analisa ini juga didukung oleh uji signifikansi dan analisa regresi serta uji normalitas.

Besar hubungan antara variabel Kompetensi Profesional Guru dengan variable kinerja Guru yang dihitung dengan koefesien korelasi adalah 0,270, sehingga terjadi hubungan yang kuat dan positif antara Kompetensi Profesional Guru terhadap Kinerja Guru. Apabila Kompetensi Profesional Guru baik maka akan diikuti kenaikan tingkat kinerja Guru pada Sekolah Menengah Atas (SMA) 1926 Tangerang Selatan. Analisa ini juga didukung oleh uji signifikansi dan analisa regresi serta uj in normalitas.

Pada Uji ANOVA terlihat hitung (1.983) lebih besar dari tabel $(2,68)$ maka Ho ditolak. Berarti variabel Supervisi Kepala Sekolah, dan Kompetensi Profesional Guru secara bersamasama ada pengaruhnya terhadap variabel kinerja Guru. Dari analisa regresi linier berganda diperoleh persamaan 83.804 '1' $0.167 \mathrm{X}_{1} 0.270 \mathrm{X}_{2}$.

\section{DAFTAR PUSTAKA}

Algifari, (2000). Analisis Regresi. Yogyakarta: BPEE-Yogyakarta

Amirullah, (2004). Pengantar Manajemen. Yogyakarta : Graha Ilmu.

Arifin, (2005). Skripsi: Peranan Kepemimpinan dalam Meningkatkan Semangat Kerja Pegawai Bojonegoro. STIE Cendekia Bojonegoro.

Barliner, David. (2000). Educational Reform in an Era of Disinformation. (http://olam.asu.edu/ epaa/vin2.html).

Fullan \& Stiegerbauer. (1991). The New Meaning of Education Change. Boston : Houghton Mifflin Company

Glover. Derek. \& Sue Law. (2005). Improving Learning Profesional Practice in Secondary Schools. Jakarta : Gramedia Widiasaran Indonesia.

Gomes. F.C. (2003). Manajemen sumber daya manusia. Yogyakarta : Penerbit Andi.

Hamzah, Awaludin, (2004). Tiga Syarat Penting Seorang Kepala Sekolah. http://www.pikiranrakyat.com
Hasibuan, Melayu S.P, (2001). Manajemen Sumber Daya Manusia. Jakarta: PT. Bumi Aksara.

Mulyasa, E, (2005). Manajemen Berbasis Sekolah. Bandung: PT. Remaja-Rosdakarya

Nasution, M.N. (2004). Manajemen Mutu Terpadu. Bogor : Ghalia Indonesia.

Rosyada, Dede, 2004. Paradigma Pendidikan Demokratis. Jakarta : Prenada Media.

Salis, E. (1993). Total Quality Management in Education. London : Kogan Paged Limited.

Sapari, Achmad. (2002). Pemahaman Guru Terhadap Inovasi Indonesia. Artikel. Jakarta; Kompas (16 Agustus 2002).

Sahertian, Piet A. (2000). Konsep-konsep dan Teknik Supervisi Pendidikan Dalam Rangka Pengembangan Sumber Daya Manusia. Jakarta : Rineka Cipta.

Seyfarth, J.T. (2002). Human Resources : Management for Effective Schools. Boston : Allyn and Bacon. Third Edition.

Sucipto. (2003). Profesionalisasi Guru Secara Internal, Akuntabilitas Profesi. Makalah Seminar Nasional. Semarang: Universitas Negeri Semarang.

Supandi. (1996). Administrasi dan Supervisi Pendidikan. Jakarta: Departemen Agama Universitas Terbuka.

Supriadi, Dedi. (1999). Mengangkat Citra dan Martabat Guru. Yogyakarta: Adicita Karya Nusa.

Suprihatin, MD. (1989). Administrasi Pendidikan, Fungsi dan Tanggung Jawab Kepala Sekolah sebagai Administrator dan Supervisor Sekolah. Semarang: IKIP Semarang Press.

Surya Mohamad. (2002). Peran Organisasi Guru dalam Meningkatkan Mutu Pendidikan. Seminar Lokakarya Internasional. Semarang : IKIP PGRI.

Timotius, (2005). Hubungan Motivasi Kerja dengan Kinerja Guru, http://www.geocities. com/guruvalah/penelitian

Townsend, Diana \& Butterwort. (1992). Your Child's School. New York : A Plime Book.

Usman, Moh Uzer. (2000). Menjadi Guru Profesional. Bandung : Remaja Rosdakarya Wardani, IGK. (1996). Alat Penilaian Kemampuan Guru (APKG). Jakarta: Dirjen Dikti. 